\title{
The Impact of Different Permissible Exposure Limits on Hearing Threshold Levels Beyond $25 \mathrm{dBA}$
}

\author{
Balachandar S Sayapathi ${ }^{1,2,}$; Anselm Ting Su ${ }^{3,4}$; David Koh ${ }^{5,6}$ \\ ${ }^{1}$ Centre for Occupational and Environmental Health, University of Malaya, Kuala Lumpur, Malaysia \\ ${ }^{2}$ Department of Ministry of Health, Kuala Lumpur, Malaysia \\ 3 Department of Community Medicine and Public Health, Faculty of Medicine and Health Sciences, University Malaysia Sarawak, Sarawak, Malaysia \\ ${ }_{4}^{4}$ Department of Community Medicine and Public Health, Faculty of Medicine and Health Scien
5 Department of Hygiene, School of Medicine, Wakayama Medical University, Wakayama, Japan \\ 5 Department of Hygiene, School of Medicine, Wakayama Medical University, Wakayama, Japan \\ 6 SSH School of Public Health, National University of Singapore, Singapore, Singapore \\ ${ }^{*}$ Corresponding Author: Balachandar S Sayapathi, Centre for Occupational and Environmental Health, University of Malaya, Kuala Lumpur, Malaysia. Tel: $+60-138049126$, Fax: +60- \\ 82442941, E-mail: balach7777@yahoo.com \\ Received: October 21, 2013; Revised: January 31, 2014; Accepted: March 11, 2014
}

\begin{abstract}
Background: Development of noise-induced hearing loss is reliant on a few factors such as frequency, intensity, and duration of noise exposure. The occurrence of this occupational malady has doubled from 120 million to 250 million in a decade. Countries such as Malaysia, India, and the US have adopted $90 \mathrm{dBA}$ as the permissible exposure limit. According to the US Occupational Safety and Health Administration (OSHA), the exposure limit for noise is $90 \mathrm{dBA}$, while that of the US National Institute of Occupational Safety and Health (NIOSH) is $85 \mathrm{dBA}$ for 8 hours of noise exposure.

Objectives:This study aimed to assess the development of hearing threshold levels beyond $25 \mathrm{dBA}$ on adoption of $85 \mathrm{dBA}$ as the permissible exposure limit compared to $90 \mathrm{dBA}$.

Patients and Methods: This is an intervention study done on two automobile factories. There were 203 employees exposed to noise levels beyond the action level. Hearing protection devices were distributed to reduce noise levels to a level between the permissible exposure limit and action level. The permissible exposure limits were 90 and $85 \mathrm{dBA}$ in factories 1 and 2, respectively, while the action levels were 85 and $80 \mathrm{dBA}$, respectively. The hearing threshold levels of participants were measured at baseline and at first month of postshift exposure of noise. The outcome was measured by a manual audiometer. McNemar and chi-square tests were used in the statistical analysis.

Results: We found that hearing threshold levels of more than $25 \mathrm{dBA}$ has changed significantly from pre-intervention to post-intervention among participants from both factories $(3000 \mathrm{~Hz}$ for the right ear and $2000 \mathrm{~Hz}$ for the left ear). There was a statistically significant association between participants at $3000 \mathrm{~Hz}$ on the right ear at 'deteriorated' level $\left(\chi^{2}(1)=4.08, \varphi=-0.142, \mathrm{P}=0.043\right)$, whereas there was worsening of hearing threshold beyond $25 \mathrm{dBA}$ among those embraced $90 \mathrm{dBA}$.

Conclusions:The adoption of $85 \mathrm{dBA}$ as the permissible exposure limit has preserved hearing threshold level among participants at 3000 $\mathrm{Hz}$ compared to those who embraced $90 \mathrm{dBA}$.
\end{abstract}

Keywords:Effects 85 or 90 dBA; Noise; Noise-Induced Hearing Loss; Threshold Shift

\section{Background}

Occupational noise-induced hearing loss is the development of hearing loss because of exposure to high levels of noise (1). There are different views with regard to the levels of noise leading to this slow and irreversible malady. According to the US Occupational Safety and Health Administration (OSHA), the permissible exposure limit is $90 \mathrm{dBA}$; an employee should not be exposed beyond this level for more than 8 hours (2). The US National Institute of Occupational Safety and Health (NIOSH), recommends $85 \mathrm{dBA}(2)$.

The lower level recommended by the NIOSH was based on a study (2) where the occurrence of material hearing impairment was lower upon adoption of $85 \mathrm{dBA}$ (as the permissible exposure limit) compared to $90 \mathrm{dBA}$. Countries such as Malaysia, India and the US adopted $90 \mathrm{dBA}$ as the permissible exposure limit. The occurrence of noise-induced hearing loss has doubled from 120 million in 1995 to 250 million in 2004 worldwide (3). Millions of workers in the US are exposed to noise levels above the permissible exposure limit. There were a total of 663 cases of occupational diseases who had been investigated in Malaysia in 2010. Around 70\% of them were diagnosed to have noise-induced hearing loss, making it the most common occupational disease (4). However, there are few studies in the literature comparing the effectiveness of adopting these permissible exposure limits on noise.

\section{Objectives}

The hearing threshold beyond 25 dBAaffects the hearing sensitivity for speech (5), both mid and high frequencies. The purpose of this study was to assess the development of hearing threshold levels beyond $25 \mathrm{dBA}$ on adoption of

Copyright (C) 2014, Iranian Red Crescent Medical Journal; Published by Kowsar. This is an open-access article distributed under the terms of the Creative Commons Attribution-NonCommercial 4.0 International License (http://creativecommons.org/licenses/by-nc/4.0/) which permits copy and redistribute the material just in noncommercial usages, provided the original work is properly cited. 
$85 \mathrm{dBA}$ (as permissible exposure limits) compared with $90 \mathrm{dBA}$. It is of utmost importance to determine scientifically adoption of the permissible exposure limit as a legal limit, since it will impose cost and enforcement issues.

\section{Patients and Methods}

\subsection{Design and Setting}

We conducted an intervention study by comparing two factories adopting different permissible exposure limits in an automobile industry in Selangor, Malaysia. This intervention consisted of using appropriate hearing protection devices among participants from both factories. Participants of factory 1 were exposed to a permissible exposure limit of $90 \mathrm{dBA}$, and those from factory 2 were exposed to the level of $85 \mathrm{dBA}$. Upon enrolment into the study, hearing threshold levels of the participants were measured at baseline and then followed up one month later. These hearing threshold levels were measured before the participants began to work at baseline, where they should not be exposed to noise levels above $80 \mathrm{dBA}$ for a period of 14 hours (6). At the first month, the hearing threshold levels were measured one hour before the end of a shift. A shift lasts for 8 hours. This study was conducted from March 2012 to April 2012.

\subsection{Subjects}

Recruitment of the study area was initiated through online requests to the safety and health officers, and the details of study information were explained. Upon approval to conduct the study, relevant information was provided to the participants. The participation of employees was voluntary and upon obtaining written informed consent. Universal sampling was applied in this study. The eligible participants were those exposed to noise level above the action level. The action level is defined as a sound level of $85 \mathrm{dBA}$ in factory 1 and $80 \mathrm{dBA}$ in factory 2 , where the daily noise doses were equal to 0.5 in both factories (6). The amount of exposure is half the dose of the permissible exposure limits. The exclusion criteria were subjects who refused to participate, contract workers (since they were not continuously employed), lorry drivers, those having ear diseases, experienced physical trauma to the ear, or undergone ear surgeries.

These particulars were obtained from a questionnaire. In factory 1, employees were working in the production control (PC) press, quality control (QC) press, welding and maintenance departments, while in factory 2 , the workers were working in PC resin, QC resin, kaizen and painting departments. There were 260 workers exposed to noise levels above the action level. Of them, 203 agreed to participate in the study. The non-respondents' excuses were their busy work schedule, or simply not willing to participate in the study. Based on the outcome a previous study (7), the required sample size was 43 respondents for each factory based on a 2-sided significance level of 0.05 and power of $80 \%$ (Table 1 ). The calculation of sample size was done by a calculation software based on the power (8). Taking into account the $20 \%$ drop out, the minimum required sample size was 52 in each factory. The sample size limitation was addressed by calling the employees through phone call and provided them incentives (food) to participate.

\subsection{Measures}

\subsubsection{Noise Area and Personal Exposure Noise Mea- surement}

Noise area measurement was measured using sound level meter (6), calibrated and approved by the Department of Occupational Safety and Health (DOSH) (Larson Davis, model Spark 706 RC and Spark $703+$ ). In factory 1 , the zones were categorized into areas of more than 90 $\mathrm{dBA}$, between 85 and $90 \mathrm{dBA}$, and below $85 \mathrm{dBA}$, whereas in factory 2 , the zones comprised areas more than $85 \mathrm{dBA}$, between the range of 80 and $85 \mathrm{dBA}$, and below $80 \mathrm{dBA}$. Sound level meters were calibrated just before and after the noise measurement. Noise exposure among employees was measured by a personal exposure noise dosimeter (6), calibrated and approved by the DOSH (Larson Davis, model Spark 706 RC and Spark $703+$ ).

The measurement was done in each job area, exceeding the action level. One employee represented a group of employees from the same job area for the measurement of noise exposure (6). The noise dosimeters were worn by the participants for the entire shift and were switched off during breaks. The average noise exposure was recorded too. The exchange rate of $5 \mathrm{~dB}$ was applied during measurement of noise. The dosimeters were calibrated just before and after noise measurement. We categorized workers calculated for the area and not the individual. This method was practiced, because within individuals, sound levels fluctuate from day to day (9). The instrument which showed a higher measured level of noise (thus causing more damage to hearing) is used for calculating noise reduction rate (NRR).

\subsection{Hearing Threshold Level}

A manual audiometer was used to collect data on hearing threshold levels of the participants in factories 1 and 2, calibrated and approved by the DOSH (model as 17 equipped with TDH-39 headphones). This audiometer was placed in a sound-proof booth, calibrated according to the Factories and Machinery (Noise Exposure) Regulations 1989 (6). Initial audiometry assessments were taken as baseline audiograms and subsequent audiometry tests were taken after one month for all participants of both factories. The test frequencies measured were 500 , 1000, 2000, 3000, 4000, 6000 and $8000 \mathrm{~Hz}$ for both ears. To increase the reliability of the measurements, two consistent readings were taken before entering them 
in the audiogram. There were two trained audiometric technicians (single observer for each worker) at a time carrying out the measurement of hearing thresholds. The measurements were done randomly on the subjects. They were blinded from the allocation arm, as they did not know which factory was adopting 85 or $90 \mathrm{dBA}$ as the permissible exposure limit during the measurement process. The same technicians carried out the assessment at the outset of the intervention and one month later.

\subsection{Intervention}

\subsubsection{Hearing Protective Device}

Hearing protection devices (6) were used to reduce noise exposure levels among participants to the levels which ranged between the permissible exposure limit and action level. These devices were distributed by the safety and health officers to participants after the initial audiometry assessments. The hearing protection devices were madeup of synthetic and corded types of ear plugs, which are reusable. To ensure continuous usage of these devices, the participants were supervised at all times during work. Noise levels of each job area were achieved by determining the appropriate NRR. There was an addition of $7 \mathrm{~dB}$ to the calculated NRR in order to convert dBA to dBC. This calculation was done since the hearing protective devices were in $\mathrm{dBC}$ units. Then, the obtained figures were multiplied by 50\% (50\% derating). NRR is calculated as follows:

Exposure of noise level in the specific job area $=$ Measured noise level $-[(\mathrm{NRR}-7) \times 50 \%](10)$ (factory 1 or factory 2 ).

In factory 1 , the perceived noise levels were reduced to intensities between 85 and $90 \mathrm{dBA}$. In factory 2 , the levels were reduced to intensities between 80 and $85 \mathrm{dBA}$.

\subsection{Compliance}

The continuous use of ear plugs among participants was insured by providing a checklist to the supervisors of both factories. We also monitored that by conducting regular spot checks to these factories on the use of these hearing protection devices.

\subsection{Blinding}

The participants and the safety and health officers were blinded to the adoption of levels of permissible exposure limits. The outcome assessors were also blinded to participants from either factory, during hearing threshold levels measurement. The statistician who analyzed the data was also blinded to factories that had embraced 85 dBA or $90 \mathrm{dBA}$ as permissible exposure limits. However, we were not blinded as the NRR was needed in each job area of both factories.

\subsection{Statistical Analyses}

The data analyses were performed using SPSS version
20 for Windows. Data from the participants who missed the follow-up were imputed by baseline values using the intention-to-treat analysis. An independent t test, chisquare test and Fisher exact test were used in the statistical analysis. A McNemar test was conducted to detect any change over hearing threshold levels beyond $25 \mathrm{dBA}$ among participants over one month. These changes were temporary threshold shifts.

If there were changes, a chi-square test for association would be conducted among participants. Hearing threshold levels would be said to be 'preserved' if the levels were at or below $25 \mathrm{dBA}$ after intervention. Before intervention, these participants had hearing threshold levels beyond 25 dBA. If the hearing threshold levels among subjects before and after intervention were at or below $25 \mathrm{dBA}$, the intervention would be said to have 'maintained preservation'. On the other hand, hearing threshold levels would be considered 'deteriorated', if the hearing threshold levels among subjects were beyond $25 \mathrm{dBA}$ after intervention. Before intervention, these subjects had hearing threshold levels at or below $25 \mathrm{dBA}$. If the hearing threshold levels among subjects before and after intervention were remained unchanged, beyond $25 \mathrm{dBA}$, then adoption of the permissible exposure limit would result in 'continue deteriorated' of hearing threshold levels. A P value of less than 0.05 was considered statistically significant.

\subsection{Ethical Considerations}

Written authorization was obtained from the relevant personnel to conduct this study in the automobile factories. Ethical approval was then obtained from the Research and Ethics Committee, University of Malaya (MEC Ref. No: 848.37). The participants' information sheets were distributed to the participants, specifying the objectives, maintenance of confidentiality and that the participants were free to opt-out at any time during the study. Contact details were given in the event the participants needed to clarify any doubts pertaining to the study. The written informed consent forms were collected before intervention.

\section{Results}

The mean age of the participants was $27.1 \pm 6.6 \mathrm{y}$. The majority of the participants were Malay male (>90\%). Most of these workers were single, and more than $60 \%$ of them had never smoked. About 3\% of these subjects had never consumed alcohol. More than one-third of these employees had only secondary or primary school education and hence, most of them earned less than RM 3000. Almost $90 \%$ of them have worked for less than 5 years. More than one-third were exposed to hobbies which may contribute to hearing loss such as listening to loud music, scuba diving, or shooting. More than one-third of them were exposed to hand-arm vibration. There were 106 participants from factory 1 and the remaining 97 of them were from factory 2. There were more than a-fifth of subjects in 
each department of both factories. The basic socio-demographic characteristics and risk factors for hearing loss were compared, as shown in Table 2. All the independent variables between the participants of two factories were not statistically different.

A chi-square test for association were conducted between factories and hearing threshold level beyond 25 dBA at 500 to $8000 \mathrm{~Hz}$ over right and left ear at baseline. All expected cell frequencies were greater than five. There were no statistically significant associations were seen at all baseline frequencies (Table 3). A McNemar test was conducted between participants in both factories with the hearing threshold level beyond $25 \mathrm{dBA}$. These associations were conducted to both right and left ears of the subjects at 500, 1000, 2000, 3000, 4000, 6000 and 8000 $\mathrm{Hz}$. The hearing threshold levels more than $25 \mathrm{dBA}$ has changed significantly from pre-intervention to post-intervention among participants from factory 1 and factory 2 at $3000 \mathrm{~Hz}$ of the right ear and $2000 \mathrm{~Hz}$ of the left ear, respectively (Tables 4 and 5).

Hence there were differences on adopting different permissible exposure limits at the first month on the hear- ing threshold level beyond $25 \mathrm{dBA}$ at these frequencies on right and left ears. A chi-square test was conducted to compare the association between participants from both factories and the change on hearing threshold level beyond $25 \mathrm{dBA}$ over one month. These associations were conducted on both right and left ears of the participants on frequencies that showed statistically significant differences in McNemar test. Fisher exact test was performed if the assumptions of chi-square were not met. There was statistically significant association between participants from both factories and change on hearing threshold level beyond $25 \mathrm{dBA}$ for the frequency of $3000 \mathrm{~Hz}$ on right ear at 'deteriorated' level $\left(\chi^{2}(1)=4.08, \varphi=-0.145, \mathrm{P}\right.$ $=0.043)$. The finding indicated that there was a weak association between the adoption of different permissible exposure limits and the worsening of hearing threshold levels. There were more participants who showed deteriorated hearing threshold levels beyond $25 \mathrm{dBA}$ despite using hearing protection devices in factory 1 adopting 90 dBA compared to factory 2 adopting $85 \mathrm{dBA}$ at $3000 \mathrm{~Hz}$ (Table 6 ). On other frequencies, no statistically significant associations were noted.

Table 1. Estimated Required Sample Size ${ }^{\mathrm{a}, \mathrm{b}}$

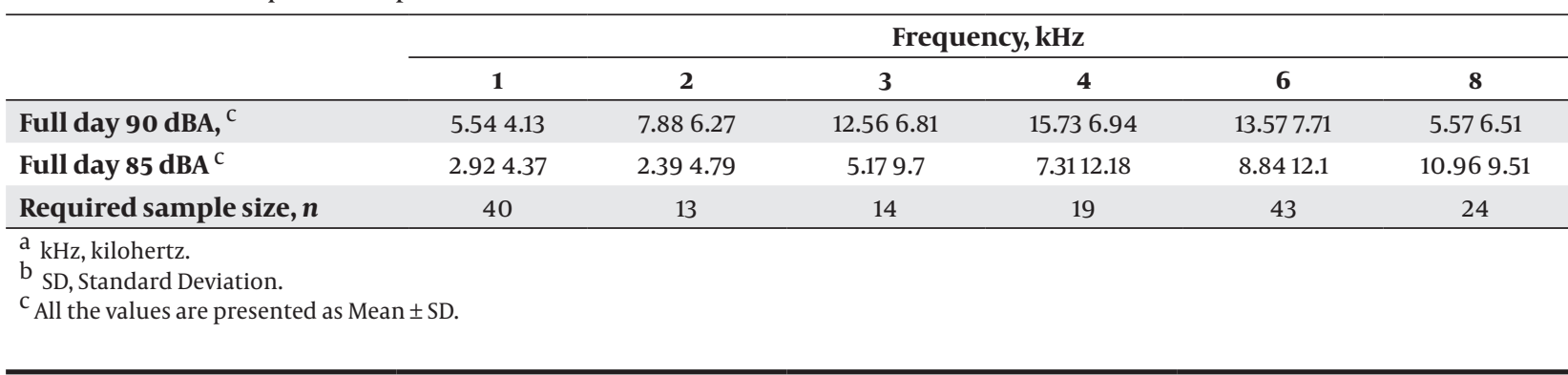

Table 2. Comparison of Independent Variables Between Participants From Factory 1 and Factory 2 a,b,c,d

\begin{tabular}{|c|c|c|c|}
\hline Characteristics/Risk Factors & Factory $1(n=106)$ & Factory $2(\mathbf{n}=97)$ & P Value \\
\hline Age, $y$ & $27.94 \pm 7.25$ & $26.22 \pm 5.60$ & $0.060^{\mathrm{a}}$ \\
\hline Duration of work & $2.45 \pm 2.11$ & $2.37 \pm 2.00$ & $0.798^{a}$ \\
\hline Smoking & & & $0.559^{b}$ \\
\hline Ever smoked & $74(69.8)$ & $64(66.0)$ & \\
\hline No smoking & $32(30.2)$ & $33(34.0)$ & \\
\hline Alcohol consumption, n (\%) & & & $0.712^{c}$ \\
\hline Ever consumed Alcohol & $3(2.8)$ & $4(4.1)$ & \\
\hline Not consumed alcohol & $103(97.2)$ & $93(95.9)$ & \\
\hline $\begin{array}{l}\text { Exposure to hand-arm } \\
\text { vibration }\end{array}$ & & & $0.098^{b}$ \\
\hline Exposed & $83(78.3)$ & $66(68.0)$ & \\
\hline Not Exposed & $23(21.7)$ & $31(32.0)$ & \\
\hline $\begin{array}{l}\text { Exposure to risky hobbies } \\
\text { for hearing loss }\end{array}$ & & & $0.582^{b}$ \\
\hline Exposed & $40(37.7)$ & $33(34.0)$ & \\
\hline Not exposed & $66(62.3)$ & $64(66.0)$ & \\
\hline
\end{tabular}


Table 3. Factories Associated With Hearing Threshold Level Beyond 25 dBA at Baseline a,b

\begin{tabular}{|c|c|c|c|c|c|}
\hline Frequency $\mathrm{Hz}$ & $\begin{array}{c}\text { Factory } 1(n=106), \\
\text { Factory } 2(n=97)\end{array}$ & $>25 \mathrm{dBA}$ & $\leq 25 \mathrm{dBA}$ & $\chi^{2}$ Statistic (df) & P Value $^{\mathrm{a}}$ \\
\hline \multicolumn{6}{|c|}{ Ear Right } \\
\hline \multirow[t]{3}{*}{500} & & & & $0.09(1)$ & 0.769 \\
\hline & 1 & $18(17.0)$ & $88(83.0)$ & & \\
\hline & 2 & $18(18.6)$ & $79(81.4)$ & & \\
\hline \multirow[t]{3}{*}{1000} & & & & $0.33(1)$ & 0.569 \\
\hline & 1 & $10(9.4)$ & $96(90.6)$ & & \\
\hline & 2 & $7(7.2)$ & $90(92.8)$ & & \\
\hline \multirow[t]{3}{*}{2000} & & & & $0.53(1)$ & 0.467 \\
\hline & 1 & $6(5.7)$ & $100(94.3)$ & & \\
\hline & 2 & $8(8.2)$ & $89(91.8)$ & & \\
\hline \multirow[t]{3}{*}{3000} & & & & $0.91(1)$ & 0.341 \\
\hline & 1 & $7(6.6)$ & $99(93.4)$ & & \\
\hline & 2 & $10(10.3)$ & $87(89.7)$ & & \\
\hline \multirow[t]{3}{*}{4000} & & & & $2.73(1)$ & 0.098 \\
\hline & 1 & $25(23.6)$ & $81(76.4)$ & & \\
\hline & 2 & $14(14.4)$ & $83(85.6)$ & & \\
\hline \multirow[t]{3}{*}{6000} & & & & $0.12(1)$ & 0.724 \\
\hline & 1 & $43(40.6)$ & $63(59.4)$ & & \\
\hline & 2 & $37(38.1)$ & $60(61.9)$ & & \\
\hline \multirow[t]{3}{*}{8000} & & & & $0.56(1)$ & 0.456 \\
\hline & 1 & $17(16.0)$ & $89(84.0)$ & & \\
\hline & 2 & $12(12.4)$ & $85(87.6)$ & & \\
\hline \multicolumn{6}{|c|}{ Ear Left } \\
\hline \multirow[t]{3}{*}{500} & & & & $0.03(1)$ & 0.874 \\
\hline & 1 & $6(5.7)$ & $100(94.3)$ & & \\
\hline & 2 & $5(5.2)$ & $92(94.8)$ & & \\
\hline \multirow[t]{3}{*}{1000} & & & & $0.02(1)$ & 0.903 \\
\hline & 1 & $7(6.6)$ & $99(93.4)$ & & \\
\hline & 2 & $6(6.2)$ & $91(93.8)$ & & \\
\hline \multirow[t]{3}{*}{2000} & & & & $0.19(1)$ & 0.662 \\
\hline & 1 & $7(6.6)$ & $99(93.4)$ & & \\
\hline & 2 & $5(5.2)$ & $92(94.8)$ & & \\
\hline \multirow[t]{3}{*}{3000} & & & & $<0.001(1)$ & 0.987 \\
\hline & 1 & $11(10.4)$ & $95(89.6)$ & & \\
\hline & 2 & $10(10.3)$ & $87(89.7)$ & & \\
\hline \multirow[t]{3}{*}{4000} & & & & $0.44(1)$ & 0.509 \\
\hline & 1 & $13(12.3)$ & $93(87.7)$ & & \\
\hline & 2 & $15(15.5)$ & $82(84.5)$ & & \\
\hline \multirow[t]{3}{*}{6000} & & & & $1.22(1)$ & 0.269 \\
\hline & & $36(34.0)$ & $70(66.0)$ & & \\
\hline & & $26(26.8)$ & $71(73.2)$ & & \\
\hline \multirow[t]{3}{*}{8000} & & & & $0.41(1)$ & 0.523 \\
\hline & 1 & $14(13.2)$ & $92(86.8)$ & & \\
\hline & 2 & $10(10.3)$ & $87(89.7)$ & & \\
\hline
\end{tabular}

\footnotetext{
a Statistical significance is based on chi-square test for independence.

$\mathrm{b}$ Data are presented as No.(\%).
} 
Sayapathi BS et al.

\begin{tabular}{|c|c|c|c|c|}
\hline \multirow[t]{2}{*}{ Frequency } & \multirow[t]{2}{*}{ Pre-intervention } & \multicolumn{2}{|c|}{ Post-intervention $(\mathbf{n}=106)$} & \multirow[t]{2}{*}{ PValue $^{a}$} \\
\hline & & $\leq 25 \mathrm{~dB}$ & $>25 \mathrm{~dB}$ & \\
\hline \multicolumn{5}{|c|}{ Ear Right } \\
\hline \multirow[t]{3}{*}{500} & & & & 0.267 \\
\hline & $\leq 25 \mathrm{dBA}$ & $84(95.5)$ & $4(4.5)$ & \\
\hline & $>25 \mathrm{dBA}$ & $9(50.0)$ & $9(50.0)$ & \\
\hline \multirow[t]{3}{*}{1000} & & & & 1.000 \\
\hline & $\leq 25 \mathrm{dBA}$ & $91(94.8)$ & $5(5.2)$ & \\
\hline & $>25 \mathrm{dBA}$ & $4(40.0)$ & $6(60.0)$ & \\
\hline \multirow[t]{3}{*}{2000} & & & & 0.219 \\
\hline & $\leq 25 \mathrm{dBA}$ & $95(95.0)$ & $5(5.0)$ & \\
\hline & $>25 \mathrm{dBA}$ & $1(16.7)$ & $5(83.3)$ & \\
\hline \multirow[t]{3}{*}{3000} & & & & 0.021 \\
\hline & $\leq 25 \mathrm{dBA}$ & $90(90.9)$ & $9(9.1)$ & \\
\hline & $>25 \mathrm{dBA}$ & $1(14.3)$ & $6(85.7)$ & \\
\hline \multirow[t]{3}{*}{4000} & & & & 1.000 \\
\hline & $\leq 25 \mathrm{dBA}$ & $76(93.8)$ & $5(6.2)$ & \\
\hline & $>25 \mathrm{dBA}$ & $4(16.0)$ & $21(84.0)$ & \\
\hline \multirow[t]{3}{*}{6000} & & & & 0.167 \\
\hline & $\leq 25 \mathrm{dBA}$ & $50(79.4)$ & $13(20.6)$ & \\
\hline & $>25 \mathrm{dBA}$ & $6(14.0)$ & $37(86.0)$ & \\
\hline \multirow[t]{4}{*}{8000} & & & & 1.000 \\
\hline & $\leq 25 \mathrm{dBA}$ & $86(96.6)$ & $3(3.4)$ & \\
\hline & $>25 \mathrm{dBA}$ & $4(23.5)$ & $13(76.5)$ & \\
\hline & & Ear Left & & \\
\hline \multirow[t]{3}{*}{500} & & & & 0.500 \\
\hline & $\leq 25 \mathrm{dBA}$ & $100(100.0)$ & $0(0.0)$ & \\
\hline & $>25 \mathrm{dBA}$ & $2(33.3)$ & $4(66.7)$ & \\
\hline \multirow[t]{3}{*}{1000} & & & & 1.000 \\
\hline & $\leq 25 \mathrm{dBA}$ & $96(97.0)$ & $3(3.0)$ & \\
\hline & $>25 \mathrm{dBA}$ & $3(42.9)$ & $4(57.1)$ & \\
\hline \multirow[t]{3}{*}{2000} & & & & 0.687 \\
\hline & $\leq 25 \mathrm{dBA}$ & $97(98.0)$ & $2(2.0)$ & \\
\hline & $>25 \mathrm{dBA}$ & $4(57.1)$ & $3(42.9)$ & \\
\hline \multirow[t]{3}{*}{3000} & & & & 1.000 \\
\hline & $\leq 25 \mathrm{dBA}$ & $90(94.7)$ & $5(5.3)$ & \\
\hline & $>25 \mathrm{dBA}$ & $5(45.5)$ & $6(54.5)$ & \\
\hline \multirow[t]{3}{*}{4000} & & & & 1.000 \\
\hline & $\leq 25 \mathrm{dBA}$ & $90(96.8)$ & $3(3.2)$ & \\
\hline & $>25 \mathrm{dBA}$ & $2(15.4)$ & $11(84.6)$ & \\
\hline \multirow[t]{3}{*}{6000} & & & & 0.424 \\
\hline & $\leq 25 \mathrm{dBA}$ & $61(87.1)$ & $9(12.9)$ & \\
\hline & $>25 \mathrm{dBA}$ & $5(13.9)$ & $31(86.1)$ & \\
\hline \multirow[t]{3}{*}{8000} & & & & 0.625 \\
\hline & $\leq 25 \mathrm{dBA}$ & 89 (96.7) & $3(3.3)$ & \\
\hline & $>25 \mathrm{dBA}$ & $1(7.1)$ & $13(92.9)$ & \\
\hline
\end{tabular}

${ }^{\mathrm{a}}$ McNemar test.

b Data are presented as No.(\%) 
Sayapathi BS et al.

Table 5. Comparison of Change on Hearing Threshold Levels Beyond 25 dBA Among Participants From Factory 2 a,b

\begin{tabular}{|c|c|c|c|c|}
\hline \multirow[t]{2}{*}{ Frequency } & \multirow[t]{2}{*}{ Pre-intervention } & \multicolumn{2}{|c|}{ Post-intervention $(n=97)$} & \multirow[t]{2}{*}{ PValue $^{\mathrm{a}}$} \\
\hline & & $\leq 25 \mathrm{dBA}$ & $>25 \mathrm{dBA}$ & \\
\hline \multicolumn{5}{|c|}{ Ear Right } \\
\hline \multirow[t]{3}{*}{500} & & & & 0.454 \\
\hline & $\leq 25 \mathrm{dBA}$ & $73(92.4)$ & $6(7.6)$ & \\
\hline & $>25 \mathrm{dBA}$ & $10(55.6)$ & $8(44.4)$ & \\
\hline \multirow[t]{3}{*}{1000} & & & & 1.000 \\
\hline & $\leq 25 \mathrm{dBA}$ & $88(97.8)$ & $2(2.2)$ & \\
\hline & $>25 \mathrm{dBA}$ & $3(42.9)$ & $4(57.1)$ & \\
\hline \multirow[t]{3}{*}{2000} & & & & 0.727 \\
\hline & $\leq 25 \mathrm{dBA}$ & $84(94.4)$ & $5(5.6)$ & \\
\hline & $>25 \mathrm{dBA}$ & $3(37.5)$ & $5(62.5)$ & \\
\hline \multirow[t]{3}{*}{3000} & & & & 0.500 \\
\hline & $\leq 25 \mathrm{dBA}$ & $85(97.7)$ & $2(2.3)$ & \\
\hline & $>25 \mathrm{dBA}$ & $0(0.0)$ & $10(100.0)$ & \\
\hline \multirow[t]{3}{*}{4000} & & & & 0.289 \\
\hline & $\leq 25 \mathrm{dBA}$ & $77(92.8)$ & $6(7.2)$ & \\
\hline & $>25 \mathrm{dBA}$ & $2(14.3)$ & $12(85.7)$ & \\
\hline \multirow[t]{3}{*}{6000} & & & & 1.000 \\
\hline & $\leq 25 \mathrm{dBA}$ & $51(85.0)$ & $9(15.0)$ & \\
\hline & $>25 \mathrm{dBA}$ & $10(27.0)$ & $27(73.0)$ & \\
\hline \multirow[t]{4}{*}{8000} & & & & 0.687 \\
\hline & $\leq 25 \mathrm{dBA}$ & $81(95.3)$ & $4(4.7)$ & \\
\hline & $>25 \mathrm{dBA}$ & $2(16.7)$ & $10(83.3)$ & \\
\hline & & Ear Left & & \\
\hline \multirow[t]{3}{*}{500} & & & & 1.000 \\
\hline & $\leq 25 \mathrm{dBA}$ & $89(96.7)$ & $3(3.3)$ & \\
\hline & $>25 \mathrm{dBA}$ & $4(80.0)$ & $1(20.0)$ & \\
\hline \multirow[t]{3}{*}{1000} & & & & 1.000 \\
\hline & $\leq 25 \mathrm{dBA}$ & $91(100.0)$ & $0(0.0)$ & \\
\hline & $>25 \mathrm{dBA}$ & $1(16.7)$ & $5(83.3)$ & \\
\hline \multirow[t]{3}{*}{2000} & & & & 0.031 \\
\hline & $\leq 25 \mathrm{dBA}$ & $86(93.5)$ & $6(6.5)$ & \\
\hline & $>25 \mathrm{dBA}$ & $0(0.0)$ & $5(100.0)$ & \\
\hline \multirow[t]{3}{*}{3000} & & & & 0.070 \\
\hline & $\leq 25 \mathrm{dBA}$ & $80(92.0)$ & $7(8.0)$ & \\
\hline & $>25 \mathrm{dBA}$ & $1(10.0)$ & $9(90.0)$ & \\
\hline \multirow[t]{3}{*}{4000} & & & & 1.000 \\
\hline & $\leq 25 \mathrm{dBA}$ & $78(95.1)$ & $4(4.9)$ & \\
\hline & $>25 \mathrm{dBA}$ & $4(26.7)$ & $11(73.3)$ & \\
\hline \multirow[t]{3}{*}{6000} & & & & 1.000 \\
\hline & $\leq 25 \mathrm{dBA}$ & $64(90.1)$ & $7(9.9)$ & \\
\hline & $>25 \mathrm{dBA}$ & $7(26.9)$ & $19(73.1)$ & \\
\hline \multirow[t]{3}{*}{8000} & & & & 0.774 \\
\hline & $\leq 25 \mathrm{dBA}$ & $80(92.0)$ & $7(8.0)$ & \\
\hline & $>25 \mathrm{dBA}$ & $5(50.0)$ & $5(50.0)$ & \\
\hline
\end{tabular}

\footnotetext{
${ }^{\mathrm{a}}$ McNemar test.

b Data are presented as No.(\%).
} 
Sayapathi BS et al.

\begin{tabular}{|c|c|c|c|c|c|c|c|c|}
\hline \multirow[t]{2}{*}{ Frequency } & \multirow[t]{2}{*}{ Ear } & \multirow{2}{*}{$\begin{array}{l}\text { Hearing Threshold } \\
\text { Level }\end{array}$} & \multicolumn{2}{|c|}{ Factory $1(n=106)$} & \multicolumn{2}{|c|}{ Factory $2(n=97)$} & \multirow[t]{2}{*}{$\chi^{2}$ Statistic $^{\mathrm{a}}(\mathbf{d f})$} & \multirow[t]{2}{*}{ PValue $^{\mathrm{a}}$} \\
\hline & & & Yes & No & Yes & No & & \\
\hline \multirow[t]{5}{*}{3000} & Right & & & & & & - & $1.000^{b}$ \\
\hline & & Preserved & $1(0.9)$ & $105(99.1)$ & $0(0.0)$ & $97(100.0)$ & & \\
\hline & & $\begin{array}{c}\text { Maintained Preserva- } \\
\text { tion }\end{array}$ & $90(84.9)$ & $16(15.1)$ & $85(87.6)$ & $12(12.4)$ & $0.32(1)$ & 0.574 \\
\hline & & Deteriorated & $9(8.5)$ & $97(91.5)$ & $2(2.1)$ & $95(97.9)$ & $4.08(1)$ & 0.043 \\
\hline & & Continue Deteriorated & $6(5.7)$ & $100(94.3)$ & $10(10.3)$ & $87(89.7)$ & $1.51(1)$ & 0.219 \\
\hline \multirow[t]{5}{*}{2000} & Left & & & & & & & $0.123^{b}$ \\
\hline & & Preserved & $4(3.8)$ & $102(96.2)$ & $0(0.0)$ & $97(100.0)$ & - & \\
\hline & & $\begin{array}{l}\text { Maintained Preserva- } \\
\text { tion }\end{array}$ & $97(91.5)$ & $9(8.5)$ & $86(88.7)$ & $11(11.3)$ & $0.46(1)$ & 0.496 \\
\hline & & Deteriorated & $2(1.9)$ & $104(98.1)$ & $6(6.2)$ & $91(93.8)$ & - & $0.155^{b}$ \\
\hline & & Continue Deteriorated & $3(2.8)$ & $103(97.2)$ & $5(5.2)$ & $92(94.8)$ & - & $0.483^{b}$ \\
\hline
\end{tabular}

\section{Discussion}

Noise-induced hearing loss is an irreversible and permanent occupational disease (11). In factory 1, around 9\% of participants had developed hearing thresholds above $25 \mathrm{dBA}$ at 'deteriorated' level, as compared with $2 \%$ from factory 2 after one-month exposure. These changes were seen at $3000 \mathrm{~Hz}$ on right ear. Noise-induced hearing loss involves frequencies ranging from 3000 to $6000 \mathrm{~Hz}$ (11). The changes were temporary threshold shifts. This finding elucidated that hearing threshold levels were more preserved when participants embraced $85 \mathrm{dBA}$ as the permissible exposure limit, instead of $90 \mathrm{dBA}$. In factory 2 , at $2000 \mathrm{~Hz}$, on left ear, around 6\% of participants developed hearing threshold levels beyond $25 \mathrm{dBA}$ as compared with $2 \%$ on those from factory 1 . However, this finding was not significant compared with those embraced 90 dBA. The employees exposed to noise level adopting $90 \mathrm{dBA}$ as the permissible exposure limit may result in more damaging effects on hearing compared with those embracing $85 \mathrm{dBA}$. Temporary threshold shifts may result in permanent shift of hearing thresholds over time, if continuous exposure to noise ensues $(12,13)$.

According to Kryter (14), the temporary threshold shifts reflected one day's exposure to noise. These mentioned temporary threshold shifts occurred two minutes after noise exposure $\left(\mathrm{TTS}_{2}\right)$. The author had also stressed that $\mathrm{TTS}_{2}$ may result in permanent threshold shifts if one is exposed to noise continuously for a longer duration. It is hypothesized that permanent threshold shifts would occur after 10 years of continuous noise insult. Kryter (14) also reported that if $\mathrm{TTS}_{2}$ was beyond $40 \mathrm{~dB}$, the recovery period of threshold shifts would get prolonged and development of permanent threshold shifts might ensue.

There are two possible mechanisms on the pathogen- esis of noise-induced hearing loss. First, the mechanical damage of stereocilia (13), and the other possible process is the metabolic damage to the hair cells in cochlea. These findings recommend countries to adopt $85 \mathrm{dBA}$ as the permissible exposure limit in order to preserve hearing thresholds and prevent hearing thresholds above $25 \mathrm{dBA}$. Consequently, the prevalence of noise-induced hearing loss is reduced.

The limitation of the study is that there was a possibility of a crossover effect of employees from two factories. This was avoided by informing the occupier the duration of this study and that the participants should be placed in the same department and factory during this study period. The measurement of personal noise exposure level was done only on one subject in each work area. The measurement was done as such because all workers in a job area were exposed to similar levels of noise intensities. This is also in accordance with the regulations for noise in Malaysia (6), where the workers in a job area are not required to undergo personal noise exposure measurement. A total of $78.1 \%$ of employees from the two factories agreed to participate. The non-respondents' excuses were their busy work procedure or their personal predilection not to participate in the study.

There were no differences between the respondents and non-respondents regarding age (mean age was 27.1 \pm $6.6 \mathrm{y}$ and $27.7 \pm 7.0 \mathrm{y}$ among the respondents and non-respondents, respectively), gender, ethnicity, and duration of work. A total of $62.6 \%$ participants were followed up until the end of the study. However, the total number of subjects who participated from both factories was more than the minimum sample size required based on the study by Yates et al. (7) and hence, the power of study was 
not affected. There were no differences between the participants who followed up and those who had dropped out regarding variables of age (the mean age was 26.8 $\pm 6.4 \mathrm{y}$ among those responded and $27.6 \pm 6.8 \mathrm{y}$ among those dropped out), gender, ethnicity, education level and duration of work. Only air conduction was used to measure hearing threshold levels in this study. To ensure that there were no damages to outer or middle ear, ear assessment was performed on all participants by otoscopic examination at baseline and then one month later. Only participants that have no damage to the ear were allowed to undergo the audiometry assessment. There were no differences in hearing threshold levels beyond $25 \mathrm{dBA}$ between participants at baseline. Hence, any changes in the hearing thresholds at post-intervention were likely due to the effect of noise.

There were no differences on confounding factors among participants of the two factories such as smoking $(15,16)$, consumption of alcohol (17), and exposure to hand-arm vibration (18). Also no significant differences were noted among participants from two factories regarding risky hobbies for hearing loss such as listening to loud noise (19), shooting (20), and scuba diving (21). Age and employment duration among employees were not significantly different. The hearing loss above $25 \mathrm{dBA}$ occurred more when participants adopted $90 \mathrm{dBA}$ as the permissible exposure limit. Hence, the countries may need to review their policy on their permissible exposure limit for noise.

\section{Acknowledgements}

This study was supported by the Postgraduate Research (Grant No. PV106/2011A) Center of University of Malaya. The authors would like to thank the Safety and Health officers of the automobile industry to assist in recruiting the participants. The authors would also like to thank all the participants who took part in the study.

\section{Authors' Contributions}

Sayapathi BS drafted the manuscript. Su AT obtained funding from the University. Su AT and Koh D supervised the entire process of the research. All authors made substantial contributions for design and revision of the manuscript. All authors approved the final manuscript.

\section{Funding/Support}

This study was supported by University of Malaya, Malaysia.

\section{References}

1. Yankaskas K. Prelude: noise-induced tinnitus and hearing loss in the military. Hear Res. 2013;295:3-8.

2. National Institute for Occupational Safety and Health. Criteria for a Recommended Standard: Occupational Noise Exposure Revised Criteria 1998.USA: DHHS (NIOSH); 1998. pp. 98-126.

3. Nelson DI, Nelson RY, Concha-Barrientos M, Fingerhut M. The global burden of occupational noise-induced hearing loss. Am J Ind Med. 2005;48(6):446-58.

4. Department of Occupational Safety and Health. . Occupational diseases and poisoning investigation. Ministry of Human Resources, Malaysia..

5. Jafari MJ, Karimi A, Haghshenas M. Extrapolation of experimental field study to a National Occupational Noise Exposure Standard. IJOH. 2010;2(2):63-8.

6. Regulations \& Rules . Laws of Malaysia.Malaysia: International Law Book Services; 2010.

7. Yates JT, Ramsey JD, Holland JW. Damage risk: an evaluation of the effects of exposure to 85 versus $90 \mathrm{dBA}$ of noise.J Speech Hear Res. 1976;19(2):216-24.

8. Dupont WD, Plummer WD, Jr. Power and sample size calculations. A review and computer program. Control Clin Trials. 1990;11(2):116-28.

9. Rubak T, Kock SA, Koefoed-Nielsen B, Bonde JP, Kolstad HA. The risk of noise-induced hearing loss in the Danish workforce. Noise Health. 2006;8(31):80-7.

10. Berger EH, Royster LH, Royster JD, Driscoll DP, Layne M. NHCA Professional guide for audiometric baseline revision.American: Industrial Hygiene Association; 2003. pp.1-796.

11. Acoem Task Force on Occupational Hearing Loss , Kirchner DB Evenson E, Dobie RA, Rabinowitz P, Crawford J, et al. Occupational noise-induced hearing loss: ACOEM Task Force on Occupational Hearing Loss. J Occup Environ Med. 2012;54(1):106-8.

12. Lawton BW. A noise exposure threshold value for hearing conservation. CONCAWE. 2001;1(52).

13. Moussavi-Najarkola SA, Khavanin A, Mirzaei R, Salehnia M, Muhammadnejad A, Akbari M. Noise-induced Outer Hair Cells' Dysfunction and Cochlear Damage in Rabbits. Iran Red Crescent Med J. 2012;14(10):647-56.

14. Kryter KD. Hazardous exposure to intermittent and steady-state noise NAS-NRC Committee on Hearing: NONR; 1965.

15. Carmelo A. Effects of cigarette smoking on the evolution of hearing loss caused by industrial noise. Health. 2010;2(10):1163-9.

16. Mahboubi H, Zardouz S, Oliaei S, Pan D, Bazargan M, Djalilian HR. Noise-induced hearing threshold shift among US adults and implications for noise-induced hearing loss: National Health and Nutrition Examination Surveys. Eur Arch Otorhinolaryngol. 2013;270(2):461-7.

17. Upile T, Sipaul F, Jerjes W, Singh S, Nouraei SA, El Maaytah M, et al. The acute effects of alcohol on auditory thresholds. BMC Ear Nose Throat Disord. 2007;7:4.

18. Iki M. Vibration-induced white finger as a risk factor for hearing loss and postural instability. Nagoya J Med Sci. 1994;57 Suppl:137-45.

19. Levey S, Fligor BJ, Ginocchi C, Kagimbi L. The effects of noiseinduced hearing loss on children and young adults. CICSD. 2012;39(1):76-83.

20. Pawlaczyk-Luszczynska M, Dudarewicz A, Bak M, Fiszer M, Kotylo P, Sliwinska-Kowalska M. Temporary changes in hearing after exposure to shooting noise. Int J Occup Med Environ Health. 2004;17(2):285-93.

21. Newton HB. Neurologic complications of scuba diving. Am Fam Physician. 2001;63(11):2211-8. 